Ovio OLARU

Institute for Scandinavian Languages and Literature, Babeş-Bolyai University

Cluj-Napoca, Romania

olaru.ovio@gmail.com

\title{
NATURE AESTHETICS. SPACE IN CONTEMPORARY SCANDINAVIAN LITERATURE
}

Recommended Citation: Olaru, Ovio. "Nature Aesthetics. Space in Contemporary Scandinavian Literature". Metacritic Journal for Comparative Studies and Theory 6.1 (2020): https://doi.org/10.24193/mjcst.2020.9.07

\begin{abstract}
This paper attempts to undertake a geo-literary analysis of contemporary Scandinavian literature, departing from the pastoral nature representations of $19^{\text {th }}$ century literary awakening and lingering on recent Scandinavian crime fiction, as this subgenre represents the Scandinavian peninsula's latest contribution to World Literature and a "temporary sub-centre" (Mads Rosendahl Thomsen) of provisional international interest. Transcending both the idyllical natural setting of romanticism and the estrangement of modernism, Scandinavian literature succeeds in re-establishing the rural as predilect locus of narrative unfolding. The paper argues that the rural miseen-scene is symptomatic for a broader ideological background, as it best reflects the ecological ethos that cuts across the peninsula's history, from the nationalistic discourse of nature to the criticism directed against the dismantling of social-democracy under the pressure of neoliberalism.
\end{abstract}

Keywords: literary geography, Scandinavian literature, crime fiction, rural space, World Literature

The Scandinavian space has long been the object of foreign fascination, regardless if it acted as mere background for Norse mythology or if it represented the picturesque setting where the modern welfare-state mythology unfolded in all its chic IKEA glory. An instrumental element for the understanding of Scandinavian literature in its proper 
context is the employment of specifically Nordic topoi, the exoticism of which has become a staple of Nordic aesthetics. Frigid landscapes, elegant lines, the impression of clear-cut, uncompromising civility and good taste: a spatial utopia where the natural landscape, barely touched by human intervention, compliments the anthropomorphic landscape, whose "atmospheric architecture" (Böhme, Aesthetics) mimics and blends into the fjordscape (Austad and Hauge 372-400), with its forests, valleys, farmhouses and crystal-clear streams.

Nature and the natural setting were the crucial elements of $19^{\text {th }}$ century Scandinavian literary discourse. For Norway in particular, the emphasis on the natural element proved to be fundamental in the creation of national specificity, as the country had ended a nearly 400-year period of Danish occupation and had signed its first official Constitution in 1814, thus setting off its literary rebirth with Henrik Wergeland's nationalistic poetry, Peter Asbjørnsen and Jørgen Moe's Folkeeventyr/ Folk Tales and, not least, with the emergence of 'The Great Four', namely Henrik Ibsen, Alexander Kielland, Jonas Lie and Bjørnstjerne Bjørnson. Whereas the romantic rendition strategically focused on Scandinavian regional specificity, reviving Viking mythology and portraying farm culture, the realist and naturalist directions unsurprisingly prioritized the only considerable urban agglomerations of $19^{\text {th }}$ century Scandinavia: Stockholm (in August Strindberg's Röda Rummet/The Red Room), Copenhagen (in the Nobel Prize-winning Danish author Henrik Pontoppidan's Lykke-Per/Lucky Per) and Christiania (in Hamsun's Sult/ Hunger). This particular shift is in no way different from other transitions from romanticism to realism and naturalism in other major European literatures. Henrik Ibsen's Peer Gynt, taking place, for the most part, in a generic Norwegian landscape, transitions to the unspecified urban milieu of A Doll's House, in much the same way Chateaubriand's Voyage en Amérique or Novalis' Hymnen an die Nachtgive way to the Paris of Emile Zola's The Ladies' Paradise. Yet the absence of proper feudal relations in Scandinavian history, as well as a greatly delayed industrialization (Swenson 513-544), coupled with a strong social-democratic tradition that prevented the exploitation of the working classes $^{1}$ from taking place to the extent

\footnotetext{
${ }^{1}$ Which it lacked in the proper sense of the word, as 19th century Scandinavia was mostly agrarian and terribly behind the more developed European states in terms of economic development.
} 
that it did in late $19^{\text {th }}$ century Great Britain, France, or the German Principalities (Cipolla), made it so that the Nordic countries lacked naturalistic works such as Gerhart Hauptmann's Die Weber/ The Weavers or Zola's La Terre/ Earth. It is because of this that the portrayal of nature is free from naturalistic elements, as the imagery associated with the rural has never been reminiscent of class struggle, poverty, isolation, and obscurantism, but has always remained within the confines of the pastoral.

On the contrary, for a considerable amount time, the Nordic countries have embarked on a conscious and large-scale project of mending inequality through putting in place a comprehensive, humane welfare system rooted in late $19^{\text {th }}$ century social democracy, borrowing elements of Lutheran dogma (Petersen 1-27), but not altogether estranged from radical leftist tendencies ${ }^{2}$. The issues addressed during the period of Det moderne gennembrud/ The Modern Breakthrough (Brandes) (mostly referring to Denmark, by far the most influential of the three at that time, but extending to emerging Norway and Sweden as well, which have adopted the term, transforming it into Det moderne gjennombrudd in Norway and Det moderna genombrottet in Sweden, but retaining its pivotal aim, that of overcoming obsolete Romanticism and „att sætte samfundsproblemer under debatt», "putting social problems up for debate») by Georg Brandes around 1870 lay the foundations for the further developments of Scandinavian literature and culture. This was, from then on, to take a strongly social critical undertone, thoroughly debating contemporary social issues, even if, as was the case with Ibsen's Doll House, that meant creating discontent with the cultural establishment.

The spatial turn at play in Scandinavian literature can be simplistically resumed to two opposing elements: the centre versus the periphery or a variation of this dichotomy. Symbolic spaces, transitional spaces, Foucauldian heterotopias (Foucault 22-27) or the intricacies of intimate "spaces we love" (Bachelard xxxv) analysed by Gaston Bachelard all fall into these two roughly outlined categories. Within Scandinavian literature, it was always the capital versus the picturesque small town and village, the seemingly borderless great outdoors - otherwise known as villmarka -

${ }^{2}$ As proven by Hans Petter Sjøli in his "Maoism In Norway and how the AKP $(\mathrm{m}-\mathrm{l})$ made Norway more Norwegian" (Scandinavian Journal of History, 33:4, 478-490, DOI: 10.1080/03468750802519982, 2008), Tauno Saarela in "Communism in Scandinavia." (Twentieth Century Communism, no. 8, 2015, p. 89-107.), or Anthony Upton in his book The Communist Parties of Scandinavia and Finland (London: Weidenfeld \& Nicolson, 1973). 
versus the intimate, familiar, or - later, during modernism - claustrophobic urban setting. "The spacious sunlight of a Western, or the ill-lit claustrophobia of a film noir." (Moretti 6) Franco Moretti speaks about how $2 \mathrm{O}^{\text {th }}$ century visual culture was dominated by the western and the noir in his Far Country. Historically, the contrast is played between the great, uncharted space of mid to late $19^{\text {th }}$ century West America and the alienating urban agglomeration of Paris, "The Capital of the Nineteenth Century", as Walter Benjamin would call it in his homonymous essay (Benjamin). The same goes for the alternating spatial imaginaries of Scandinavian literature: August Strindberg's nature-inspired mysticism transforms into the alienating, corrupt Stockholm mirrored on the walls of the red dining room where the aspiring civil servant Arvid Falk finds refuge among the capital's intelligentsia in The Red Room. Likewise, Knut Hamsun's dehumanising landscape of poverty, hunger and voyeurism in Oslo in his 1890 Hunger is preceded by Bjørnstjerne Bjørnson's pastoral peasant novels published between 1857 and 1868 (Synnøve Solbakken (1857), Arne (1858), En glad Gut (A Happy Boy) in 1860, and Fiskerjentene (The Fisher Girls) in 1868). Henrik Pontoppidan's Lucky Per is preceded by his Det forjættede Land/Emanuel, children of the Soil, published in three parts between 1891 and 1895 .

The rural imagery is kept alive in the absence of a proper rural setting in Jon Fosse's nynorsk dialect or in Tarjei Vesaas' The Ice Palace, but transcends its formal function in Sigrid Undsett's Kristin Lavransdatter, becoming a character of its own. Borrowing Maurice Blanchot's aphorism, "to write is to surrender to the fascination of time's absence" (Blanchot 29), but Undset's attention to detail and respect for historical authenticity in portraying $14^{\text {th }}$ century Norway makes the spatio-temporal component of the book an entity of its own, so specific as to acquire agency, since the novel opens with the prophecy revealed to Kristin in her reflection on the surface of an eerie forest pond and ends with her death in a nunnery by the Black Plague that had reached the land in 1349. Turn-of-the-century Christiania is for Knut Hamsun's Hunger what Stockholm becomes in Strindberg's The Red Room and what Copenhagen represents for Henrik Pontoppidan's Lucky Per: a character, by much the same fashion in which Paris is the second author of Balzac's Human Comedy, Dublin is mirrored in Leopold Bloom's every step in Ulysses and Venice is the fatalistic agent behind the narrator's demise in Death in Venice. Franco Moretti proves it quite literally in his Atlas of the European Novel 
180o-190o, as well as in Graphs, Maps, and Trees: characters are often overshadowed by the powerful presence of the spaces they inhabit. 3

Even the most urban novelists such as Lars Saabye Christensen, depicting throughout his entire career - life in the state capital of Norway, Oslo, resorts to many elements pertaining to pastoral imagery: not only is Oslo not a proper example of urban agglomeration, as the population density is quite low, the city is also a landscape of idyllic suburbia, as parks and recreational green spaces abound and as most of the city's families live in houses; moreover, Lars Saabye Christensen's narrator Barnum, from the 2001 Halvbroren/ The Half Brother, usually depicts the city through a thick nostalgic lens, "musealizating" (Lübbe) it, transforming it into an object of nostalgic fetishism for a space belonging rather to memory than geo-temporally definable. Christensen proves the "expansive historicism of our contemporary culture, a cultural present gripped with an unprecedented obsession with the past” (Huyssen 31), but he is not alone. Kim Leine's 2012 Profeterne i Evighedsfjorden/ The Prophets of Eternal Fjord re-enacts with naturalistic accuracy the Danish missionary movement in Greenland, departing from the same barren and icy landscape described in Peter Høeg's 1992 Frøken Smillas Fornemmelse for Sne/Miss Smilla's Feeling for Snow, which portrays, within a crime fiction story, the contemporary remnants of Danish colonialism in Greenland, as well as the remains of Danish welfare infrastructure. The death of Isaiah, the son of Smilla's alcoholic neighbour, on account of him being chased off a rooftop during a snowy winter night is reminiscent of Hanne Ørstavik's 1997 Kjærlighet/Love, set likewise during a dark winter night in the far North of Norway, or her 2000 novel Tiden det tar/The Time it Takes, where the cold and isolation act as metaphors for familial estrangement. All these novels, however, are preceded by Tarjei Vesaas' 1963 Is-Slottet/ The Ice Palace, set in an unspecified northern village in Norway, depicting, from its very first paragraph, the outside as a cold, snowy, dark, inhospitable place, yet conserving the heterotopia of

3 "a literary geography, however, can refer to two very different things. It may indicate the study of space in literature; or else, of literature in space. In the first case, the dominant is a fictional one: Balzac's version of Paris, the Africa of colonial romances, Austen's redrawing of Britain. In the second case, it is real historical space: Provincial libraries of Victorian Britain, or the European diffusion of Don Quixote and Buddenbrooks. The two spaces may occasionally (and interestingly) overlap, but they are essentially different." (Moretti, Atlas 3). 
the Ice Palace itself, a thoroughly frozen cascade that acts as the novel's central metaphor.

Scandinavian literature has retained its inherent pastoralism throughout its history, not least because of a deeply engrained preoccupation with healthy living and a strong relationship to nature, brought about by a marked eco-socialist education stressing the importance of civic duties, social cohesion, and respect for the environment. Nature writing - and natural settings, implicitly - is unsurprising in Norway, Sweden, Finland or Denmark, since the countries abound in undisturbed natural landscapes and a clear distinction between the rural and the urban is virtually non-existent due to an historically uniform economic development throughout their provinces. The underlying ecologism of Marxist theory claims that "it is capitalism which ardently defies the inherited separation of nature and society" (Smith 7). If so, the Scandinavian perception of space must be a pre-capitalist one or, following ecocritical interpretations, a post-capitalist one (Hennig, Jonasson, and Degerman), as they seem to have developed "a mature environmental aesthetics" going "beyond the closed circuit of pastoral and antipastoral to achieve a vision of an integrated natural world that includes the human" (Gifford 148).

The triumph of the Scandinavian economic middle way, the high levels of subjective well-being recorded in the Nordic countries, the unprecedented levels of trust in the government and in fellow citizens (Rothstein 450), which have been a Nordic staple during much of Scandinavia's post-war history (Hilson), have, however, slowly begun to subside, as private pressures in the economy have slowly eroded the welfare state and demasked its presumed bureaucratization, its suffocating paternalism, its lack of proficiency and overall failure in catering to the needs of the lower classes. Perhaps the most significant transformation that has taken place in Scandinavia regards not only the partial or total privatization of state-owned enterprises, but also the erosion of social cohesion, regarded by many as one of the most important factors behind the success of Nordic politics and as a significant component of regional specificity (Tsarouhas). This, in turn, has given rise to the strong emergence of a specifically Nordic crime fiction wave, better known under the name of Scandinavian Noir, which employs space in two ideologically opposing, yet very recognisable manners: the critical and the marketable, best summarized through Folkhemsnostalgin and Scandimania, respectively. 
1. In the armchair tradition of crime fiction, emphasis was put on the murder scene: on scene in general, as the allure of intelligent entertainment armchair narratives provided made it necessary that every piece of furniture, every element of spatial nature mentioned en passant play a role in the decoding of the story. A loose button, an unorderly shirt collar, a book on the mantelpiece: not only is space not confined to geographical or even spatial cues per se, as the narrative is constructed in nonlinear fashion around a seemingly impenetrable murder scene, on which the subsequent narrative progression falls back, but it is an ideological statement, a relic of the Aristocratic conserved within the conventions of a bourgeois genre. More than a simple order of things displaced by murder, space in armchair detective novels is a world-order disturbed by a social phenomenon altogether foreign to it. Armchair detectives are, within the crime fiction genre, the equivalent of the mentally insane Christian Buddenbrook or typhus-stricken Hanno in The Buddenbrooks or Baron de Charlus being blackmailed by his servant lovers in Proust's In Search of Lost Time: the swan song of $19^{\text {th }}$ century high bourgeoisie, confronted with the concreteness of a world just outside its borders.

However, in the hardboiled tradition that came to embody said world and that followed the Golden Age of armchair detectives, the ideology of space reflected the ideological shift of modernism itself: space became quintessentially urban, as Raymond Chandler set his private eye, Philip Marlowe, in Los Angeles, and as Dashiell Hammett's Continental Op and Sam Spade worked in San Francisco: the "mean streets" became the predilect locus for the archetypical figure of American exceptionalism, a generic "tough guy" (Abbott) for whom no challenge could be too great, a novelistic enclave abounding in "simple plots, the range and richness of formulaic metaphors" (Bercovitch 358).

In the police procedural subgenre that gained prominence after the hardboiled tradition, the urban space maintains its importance, as illustrated by Ed Mcbain's 87th Precinct novels, set in the city of Isola, a fictionalized version of New York, or by Georges Simenon's Inspector Maigret, from Paris. The metropolitan areas depicted show the tedium of police work in all its unspectacular glory, much like Maj Sjöwall and Per Wahlöö's 10 instalments of Roman om ett brott/ Novel about a crime do, combining the unfeigned brutality of rising criminality in Stockholm's neighbourhoods with the bureaucratization and rigid hierarchy of the welfare state. The crime fiction duo is 
responsible for giving voice to a crucial sentiment cutting across the majority of Scandinavian crime fiction written in their wake: folkhemsnostalgin, designating the nostalgia after the Swedish - and Scandinavian through a generous extension - people's home, a yearning after a corroded welfare state whose universal policies have not only created the long-term Scandinavian prosperity, but also generated, for a brief twodecades span after the Second World War, the promising image of a universalizable middle way between the two ideological poles of the Cold War. Departing from the idea that the welfare state has become a local rendition of international capitalism and that it ceased to cater to the needs of its own population, Sjöwall and Wahlöö's Roman om ett brott is placed, for the most part, in a notably urbanized, alienated Stockholm, comprised mainly of old, neglected and oftentimes uninhabitable apartment blocks, and populated by typologies of urban decay: pensioners living in extreme poverty, abandoned by the state, unemployed youngsters, alcoholics, drug users, and prostitutes. The entire setting is reminiscent of the noir aesthetic of Fritz Lang's $1931 M$, as the ten instalments of the book are as much a crime fiction novel as an anti-capitalist political statement. All throughout the books, capitalism is equated to moral degradation, alienation, and violence, regardless of whether we consider Roseanna, the young and promiscuous American woman whose murder opens the series, the murder spree taking place in an inner city bus, investigated by Martin Beck, or the underwhelming assassination of the Swedish prime-minister in the last book, Terroristerna/ The Terrorists, by a very young and very naïve woman disappointed by the state. In the series' particular case, the urban setting is set against the backdrop of a yearned-for rural retreat, which materializes solely when Beck has to solve cases outside of Stockholm, a seldom occurrence. "The link between the supposed real and its fantasy representation was mainly woven by maps" (Westphal144), and the books abound in maps, as every investigation, home visit or route taken by patrolling "snutar" is closely observed and documented by means of street names and recognizable Stockholm landmarks. In part owing to a narrative strategy consciously employed by the two authors in socialist realist manner and part owing to the realist genre convention, the highly detailed description of Stockholm pushes the folkhemmet further away, as even reclusive and seemingly intangible rural settings become murder scenes, in Roseanna as well as in Polismördaren/Cop Killer, where the small town of Anderslöv offers a glimpse 
into a rural Scandinavia which is no longer rural in the proper sense, but which helps many Scandinavian Noir narrative voices (Håkan Nesser's Van Veeteren, Camilla Läckberg's Erika Falck or Henning Mankell's Kurt Wallander, living out his alcoholism in the Swedish small town of Ystad) establish an emotional, nostalgia-laden bond to a socio-political system which has but almost entirely vanished. "Seemingly, this pastoral ideal extends all the way back to Eden, where each occasion for nostalgic longing is but another way to bemoan the present status quo" (Tally87): precisely this naive conservatism lies at the heart of folkhemsnostalgin and transforms the initial wave of Scandinavian Noir authors, up until the 2004 publication of Stieg Larsson's first instalment in the Millenium series, into representatives of an anti-reactionary return to the values that had established the modern Nordic welfare mythology, indeed, those that had turned it into an international political brand since as early as 1936 (Childs). Moreover, the employment of space continues the social-critical project of 'The modern Breakthrough' by inventing - making use of the genre's conventions and inherent exaggerations - criminal worlds, which it then attempts to dismantle, showing glimpses of Scandinavian society's presumed invisible underbelly - regardless of whether it is Sweden's immigration policy in Henning Mankell's 1991 Mördare utan ansikte/Faceless Killers, where a crime in an isolated farmhouse in Skåne by a killer presumed to be of foreign descent spurns a wave of anti-immigrant sentiment in the region, or in Karin Fossum's 2000 Elskede Poona/Calling Out to You, where a recently emigrated Indian woman is killed in mysterious circumstances, or the networks of organized crime uncovered by Kurt Wallander in Mankell's 1995 Villospår/Sidetracked.

Space as a site for critique usually entails either portraying the transformation of pastoral settings into crime scenes due to a general increase in criminality in countries where it has been traditionally low, an increase attributable to the weakening of the welfare state, or the transformation of otherwise peaceful urban milieus into alienating, materialistic metropoles or capitals of international crime.

2. The opposing stance refers to the employment of Scandinavian landmarks and recognizable tropes in a form of cultural tourism. Much like the interest in Scandinavian literature briefly kindled transnationally in the second half of the $19^{\text {th }}$ century, as Ibsen's plays were staged all throughout Europe and as Georg Brandes announced 'the modern breakthrough', or as Hans Christian Andersen gained the popularity that was to boost 
him among the top ten translated authors of all time (Talar xvi), Scandinavian crime fiction has once again become, to borrow Mads Rosendahl Thomsen's expression, the "temporary sub-centre" (Thomsen 35) of international attention. A sub-centre inasmuch as it cannot threaten the canonical hegemony - not least because it belongs to a genre that has been long frowned upon as light entertainment -, the interest in the recent wave of Nordic crime writers is temporary to the extent that the modern book market is volatile and profit-driven, following international readership trends which, in turn, have determined authors to attempt to cater to mainstream tastes and to renounce their uncompromising aesthetic autonomy; in this way, literary enclaves such as Scandinavian Noir fall out of fashion as swiftly as they gained their popularity in the first place, since the genre itself is exhausted by the very positive feedback loop it sets in motion. Crucial for the whole process of this internationalization is the creation of a "Scandimania" (Thomson and Nielsen 237-268) by means of a carefully staged marketing scheme engaging different elements of Nordic aesthetics, such as fjords, gloomy weather, endless forests, modern architecture, and isolated farmhouses amounting to a 'mixture of bleak naturalism, disconsolate locations and morose detectives'(Creeber 21-35), but also elements pertaining to the perceived image of Scandinavian social-democracy: bureaucratization, hierarchy in the police force, and a carefully enacted procedure of crime-solving respected by nearly every novel.

The opposite of cultural tourism resumes itself to presenting the exotic as commonplace occurrence or omitting it altogether, as if its presence was natural, indeed, as if the author's very Weltanschauung would not include it on account of it being too mundane. In this sense, the specifically Nordic elements become visible only as they are emphasized strategically in the attempt to turn them into a selling point. Borrowing the concept of "born translated" from Matthew Kirschenbaum, but changing its deeper connotations, I argue that some novels, besides being published in several languages simultaneously, are actually written specifically in order to be translated as soon as possible (Walkowitz). The usual practice of literary agents negotiating translations on behalf of the superstar authors they represent makes it so that, more often than not, translation rights are sold way before the very books are written. Even if written for translation in the hopes of acquiring an international reach and attention, Scandinavian Noir novels still retain their Nordic touch, in the sense that they 
extensively make use of Nordic tropes such as names, cultural traditions, Scandinavian social cues, poorly disguised hints of a specifically Scandinavian social system, with its inherent and implicit rules, and immediately recognizable Scandinavian concepts such as hygge - the ultimate Scandinavian spatial fetishism - or fika. They are, at a smaller scale, name-dropping with the aim of conserving a false Nordic exoticism about countries that are, in fact, not much different from the rest of Western Europe. In this way, the process of the novels' international dissemination follows what I have called the cosmopolitan circuits of translation, comprised mainly of first-world countries, for whose readerships these references are being devised in the first place: cosmopolitan, educated, middle-class readerships that have to be appeased through recognizable, slightly exotic, but not altogether undecipherable tropes. "Buying the book, a reader becomes part of an international community. This perception adds to the book's attraction." (Parks).

Alongside the commodification of Nordic imagery, the other predilect symbolic space employed as selling point for Scandinavian Noir novels is the state. There are two elements at play here. On the one hand, the genre is transforming agents of the state into charismatic, rebellious, troubled, idiosyncratic, or promiscuous figures meant to humanize the police force and indirectly cultivate readers' sympathies for the allprotective and all-inclusive state itself. On the other hand, the state is, as Max Weber discusses in his Politics as a Vocation lecture, "regarded as the sole source of the "right" to use violence" (Weber 33). Therefore, the novels oftentimes depict its trusted hand, the police force, as being abusive, incompetent, corrupt or wanting, in order to provide a platform for fashionable anti-state critique, shared mostly among the more progressive, liberally inclined segments of the cosmopolitan readership:

In the wake of the radicalization of the genre in the 1960s and 1970s by writers like Chester Himes, Jean-Patrick Manchette, and Maj Sjöwall and Per Wahlöö, combined with a growing belief in the capacities of the crime novel to confront the ills of the system, certain novels offered more explicit critiques of state corruption and the surrender of the public 'good' to private interests. (Pepper and Schmid 5) 
In conclusion, regardless if we are talking about the touristic gaze of "Norientalism" (Hauge 237-255) deeply rooted in $19^{\text {th }}$ century travelogues and the commodification of tourism (Sondrup, Sandberg, DuBois, and Ringgaard 481), or about an artificial protest against the neoliberal overtake through the lingering of a folkhems-nostalgic sentiment and the emphasis of Nordic cultural exceptionalism, when we look at a historic cross section of Scandinavian literary tradition, one thing is clear: in Scandinavian culture (and implicitly also in the whole modern history of Scandinavian literature), the spatial tropes pertaining to the rural, the pastoral, and the natural, compose, alongside the literary subject, an "ecological nature-aesthetics" (Böhme, Naturästhetik). Within this understanding of space, man - and all his literary renditions: the detective, the urban voyeur, the historical figure, and the mythical hero - is organically linked to the space he inhabits. The Scandinavian representation of space has never been really affected by economically legitimated geoengineering attempts thanks to a constant preoccupation with environmentalism so deeply engrained in Scandinavian culture as to become unnegotiated cultural praxis most clearly visible in the field of literary representation.

\section{References:}

Abbott, Megan E. The Street Was Mine. White Masculinity in Hardboiled Fiction and Film Noir. New York: Palgrave Macmillan, 2002.

Austad, Ingvild, Hauge, Leif. „The «Fjordscape» of Inner Sogn, Western Norway”. Jones, Michael, Olwig, Kenneth R. (eds.). Nordic Landscapes. Region and Belonging on the Northern Edge of Europe. Minneapolis; London: University of Minnesota Press, 2008, pp. 372-400.

Bachelard, Gaston. The Poetics of Space. Boston:Beacon Press, 2004.

Benjamin, Walter. The Writer of Modern Life. Essays on Charles Baudelaire. Cambridge; Masschusetts; London: Harvard University Press, 2006.

Bercovitch, Sacvan. The Rites of Assent. London: Routledge, 1993, p. 358.

Blanchot, Maurice. The Space of Literature, trans. by Ann Smock. London; Lincoln: University of Nebraska Press, 1989.

Böhme, Gernot. Für eine ökologische Naturästhetik. Frankfurt am Main: Suhrkamp, 1989. 
Böhme, Gernot. The Aesthetics of Atmospheres. New York; London: Routledge, 2017.

Brandes, Georg. Hovedstrømninger $i$ det 19de aarhundredes litteratur. Emigrantlitteraturen, second revised edition. Copenhagen: Gyldendalske Boghandels Forlag, 1877.

Childs, Marquis William. Sweden: The Middle Way. New Haven: Yale University Press, 1936.

Cipolla, Carlo M. (ed.). The Fontana Economic History of Europe. The Emergence of Industrial Societies. Part 1. Glasgow: Fontana/Collins, 1973.

Creeber, Glen. "Killing Us Softly: Investigating the Aesthetics, Philosophy and Influence of Nordic Noir Television”. Journal of Popular Television 3(1)/ 2015, pp. 21-35.

Foucault, Michel. "Des Espaces Autres (Of Other Spaces: Utopias and Heterotopias)”. Architecture, Mouvement, Continuité, no. 5 (October 1984), pp. 46-49; trans. by Jay Miskowiec. Diacritics 16, no. 1 (Spring, 1986), pp. 22-27.

Gifford, Terry. Pastoral. London; New York: Routledge, 1999.

Hauge, Hans. "Det grønlandske spøgelse: Peter Høegs Smilla." Spring: Tidsskrift for Dansk Litteratur 22/2004, pp. 237-255.

Hennig, Reinhard, Jonasson, Anna-Karin, and Degerman, Peter (eds.). Nordic Narratives of Nature and the Environment: Ecocritical Approaches to Northern European Literatures and Cultures. New York; London:Lexington Books, 2018.

Hilson, Mary. The Nordic Model. Scandinavia Since 1945. London: Reaktion Books, 2008.

Huyssen, Andreas. "Present Pasts: Media, Politics, Amnesia." Public Culture 12, no. 1 (2000), pp. 21-38.

Kirschenbaum, Matthew. Mechanisms: New Media and the Forensic Imagination. Cambridge, MA: MIT Press, 2008.

Lübbe, Hermann. Zeit-Verhältnisse: Zur Kulturphilosophie des Fortschritts. Graz: Styria Verlag, 1983.

Moretti, Franco. Atlas of the European Novel 180o-190o. London; New York:Verso, 1998.

Moretti, Franco. Far Country. Scenes from American culture. New York: Farrar, Strauss and Giroux, 2019. 
Parks, Tim. „The Dull New Global Novel.” The New York Review of Books, February 9, 2010, https://www.nybooks.com/daily/2010/02/09/the-dull-new-global-novel [10.05.2020].

Pepper, Andrew, Schmid, David (eds.). Globalization and the State in Contemporary Crime Fiction. A World of Crime. New York: Palgrave Macmillan, 2016.

Petersen, Jørn Henrik. "Martin Luther and the Danish Welfare State". Lutheran Quarterly, Volume 32, Number 1, Spring 2018, pp. 1-27.

Rothstein, Bo. "Happiness and the Welfare State". Social Research: An International Quarterly, Volume 77, Number 2, Summer 2010, pp. 441-468.

Saarela, Tauno. "Communism in Scandinavia." (Twentieth Century Communism, no. 8, 2015, p. 89-107.),

Sjøli, Hans Petter. "Maoism In Norway and how the AKP(m-l) made Norway more Norwegian". Scandinavian Journal of History, 33:4, 478-490, DOI: 10.1080/03468750802519982, 2008.

Smith, Neil, Uneven Development. Nature, Capital, and the Production of Space, 3rd edition, Athens; London: The University of Georgia Press, 2008.

Sondrup, Steven P., Sandberg, Mark B., DuBois, Thomas A., and Ringgaard, Dan (eds.). Nordic Literature. A comparative history. Volume 1: spatial nodes. Amsterdam; Philadelphia: John Benjamins Publishing Company, 2017

Swenson, Peter. "Bringing Capital Back In, or Social Democracy Reconsidered: Employer Power, Cross-Class Alliances, and Centralization of Industrial Relations in Denmark and Sweden." World Politics, 43(04)/ 1991, 513544. doi:10.2307/2010535.

Talar, Maria. "Denmark's Perfect Wizard. The Wonder of Wonders”. Tartar, Maria (ed.), The Annotated Hans Christian Andersen. New York; London: Norton. 2008, xvi., cited in Sanders, Karin. "A Man of the World: Hans Christian Andersen". Ringgaard, Dan, Thomsen, Mads Rosendahl (eds.). Danish Literature as World Literature. New York; London: Bloomsbury Academic, 2017, pp. 91-114.

Tally, Robert T. Spatiality. New York; London: Routledge, 2012, p. 87.

Thomsen, Mads Rosendahl. Mapping World Literature. International canonization and transnational literatures. New York; London: Bloomsbury Academic, 2009, p. 35 . 
Thomson, C. Claire, Stougaard-Nielsen, Jakob. “'A faithful, attentive, tireless following': Cultural Mobility, Crime Fiction and Television Drama”. Ringgaard, Dan, Thomsen, Mads Rosendahl (eds.). Danish Literature as World Literature. New York; London: Bloomsbury Academic, 2017, pp. 237-268.

Tsarouhas, Dmitris. Social Democracy in Sweden. The Threat from a Globalized World. London; New York: Tauris Academic Studies, 2008.

Upton, Anthony. The Communist Parties of Scandinavia and Finland. London: Weidenfeld \& Nicolson, 1973.

Walkowitz, Rebecca L. Born Translated. The Contemporary Novel in an Age of World Literature. New York: Columbia University Press, 2015.

Weber, Max. The Vocation Lectures, Edited and with an Introduction by David Owen and Tracy B. Strong, Trans. by Rodney Livingstone. Indianapolis; Cambridge: Hackett Publishing Company, 2004.

Westphal, Bertrand. The Plausible World. A Geocritical Approach to Space, Place, and Maps, trans. by Amy D. Wells. New York: Palgrave Macmillan, 2013. 